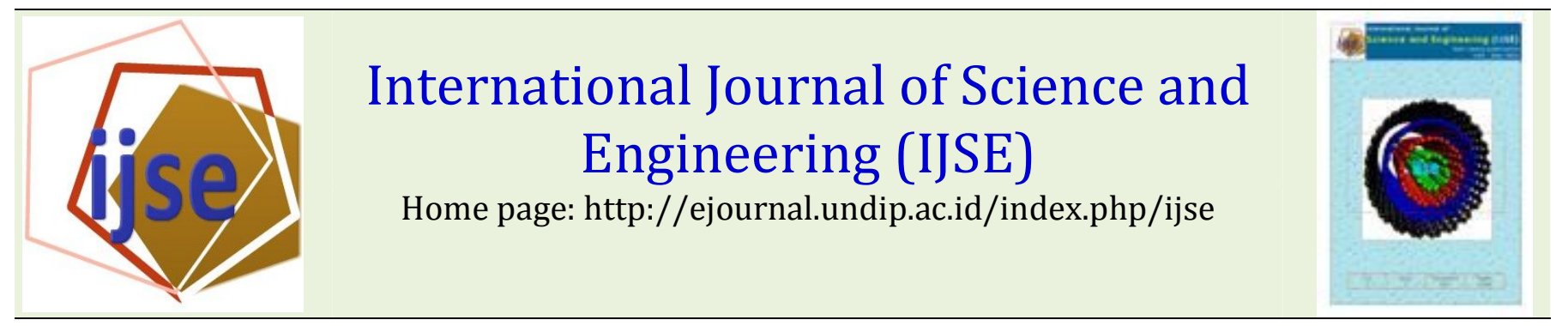

\title{
Evaluation of conductive polymers as an adsorbent for eradication of As (III) from aqueous solution using inductively coupled plasma optical emission spectroscopy (ICP-OES)
}

(1)Muhammad Imran Din, (1)Sadia Ata, (2)Ijaz Ul Mohsin, (1)Ata Rasool, (1)Andleeb Andleeb Aziz

(1) Institute of Chemistry, University of the Punjab, Lahore, Pakistan

(2)Department of Chemistry, University of Engineering \& Technology, Lahore, Pakistan

Corresponding Author: imrandin2007@gmail.com

\begin{abstract}
The main focused of this research work is the preparation of conductive polymers like polypyrrole, polyaniline and polythiophene and their application as adsorbent materials for the removal of hyper toxic metal As (III) from aqueous solution. The metal ions get attached on the $\pi$-electrons at the back bone of polymer that illustrate excellent affinity for metal ions. The adsorption of As (II) ions was carried out on polythiophene due to its redox properties and the stronger interaction between sulfur atoms with arsenic atoms. To attain large surface area and for maximum interaction of As (III) ions with polymers, the particle size of polymers was ranged in nano scale. As the surface area increases with decrease in particle size, the active sites for metal ions also increases. These polymers were characterized by FIIR spectroscopy and SEM analysis. Adsorption isothermal data was examined by two parameters (Langmuir, Freundlich, and Dubinin-Radushkevich) and three parameters Redlich-Petrson, Sips and Toth models. Experimental results showed that based on standard deviation (SD) and Chi square test $\left(\chi^{2}\right)$ the experimental data was best explained by Freundlich and Toth isotherm. Thermodynamics parameters such as free energy change $\left(\Delta G^{0}\right)$, enthalpy change $\left(\Delta H^{0}\right)$ and entropy change $\left(\Delta S^{0}\right)$ have been calculated respectively, which revealed the spontaneous, endothermic and feasible nature of adsorption process.

Key Words - Conductive polymers, polypyrrole, polyaniline, polythiophene, Arsenic
\end{abstract}

Submission: 1 December 2013

Corrected : 24 March 2014

Accepted: 10 April 2014

Doi: $10.12777 /$ ijse.6.2.154-162

[How to cite this article: Din, M.I., Ata, S., Mohsin, I.U., Rasool, A., Aziz, A.A. 2014. Evaluation of conductive polymers as an adsorbent for eradication of As (III) from aqueous solution using inductively coupled plasma optical emission spectroscopy (ICP-OES). International Journal of Science and Engineering, 6(2),154-162. Doi: 10.12777/ijse.6.2.154-162]

\section{Introduction}

Conductive polymers due the presence of $\pi$-electrons and unique properties such as mechanical strength, electrical conductivity, electrochemical properties and simplicity of processing, become attractive in the last few decades (Lashkenari, Davodi et al. 2011). Polypyrrole is a conducting polymer and formed by connected pyrrole rings. They are basically polyacetylene derivatives(Ansari and Fahim 2007). This polymer has conjugated double bonds and is being using in the different applications. It has multifunctional properties like ion exchange and material for separation (Vidal, García et al. 1999). Conducting polymer provide much different properties and now can be used as adsorbent for different metals. Industrial effluents have many poisonous materials and metals. These metals leached down to the drinking water and causes diseases. These metals are easily adsorbed and thus enter into the food chain (Carvalho, Vignado et al. 2008). Process for the preparation of polypyrrole reduced grapheme oxide composites. Good production, high adsorption capacity and regeneration of polymer properties make this material 
practically useful for waste water treatment (Zhao, Lv et al. 2011)

Arsenic is a highly toxic element and has many adverse effects on human health. Like it is carcinogenic, and widely present in human tissues, hair, skin nail Drinking water is a major source of arsenic (Lo, Jeng et al. 1997). The major source of arsenic in drinking water is herbicides fungicides and insecticides. The allowed concentration of arsenic is reported by (USEPA) is $10 \mu \mathrm{g} / \mathrm{L}$. The toxicity of arsenic is due to its ability to react with sulfhydryl groups and blocked the thiol groups of enzymes. The arsenic toxicity is determined by its oxidation state (Kumaresan and Riyazuddin 2001) .

Removal of arsenic from contaminated water is very tough task for the authorities. Different polymers had also been used for the removal of arsenic. Many iron coated polymer were used for the removal of arsenic. They modified the polystyrene for the removal of arsenic. Adsorption is one of the effective techniques for removal of metals (Katsoyiannis and Zouboulis 2002).

It has been found that there are many conductive polymers that have been used for heavy metal removal. Polypyrrole, polyaniline proved to be very effective for heavy metal ions removal (Ansari and Fahim 2007). There is very little literature that reported thiophene as adsorbent for metal ions. Thiophene contain sulpher atom and this proved to be high affinity for metals ion and give strong interaction $\pi$-conjugated polymer had many applications and it is predicted that it will become an integral part of future electronic molecular self-assembly is the important synthesis method in which functionality and uses of $\pi$ conjugated system, enhanced. The ion carrier property of the conductive polymers is influenced by morphology. Polythiophene has mostly controlled molecular structure and side chain aggregation. Such polymers have high ions carrier mobility. In such type of polymers the electrons are largely delocalized. These properties of polymer have attracted the interest of scientists polythiophene is an electron donating unit. The intermolecular charged structure along the polymer chain is responsible for ionexchange properties.

In current research work, conductive polymers polypyrrole, polyaniline and polythiophene were prepared and were used for the removal of As (III) from water. The different adsorption parameters were applied such as, temperature, $\mathrm{pH}$ and contact time. Polythiophene was synthesized with different oxidants like $\mathrm{CuSO}_{4}$ and $\mathrm{FeCl}_{3}$. The main objective of research was to synthesize, characterize and to investigate the adsorption properties of polypyrrole, polyaniline and polythiophene for As (III) ions removal from aqueous solution.

\section{Material and Methods \\ 2.1 Chemicals and Reagents}

Pyrrole $\left(\mathrm{C}_{4} \mathrm{H}_{5} \mathrm{~N}\right)$ Merck (98\%), Aniline $\left(\mathrm{C}_{6} \mathrm{H}_{7} \mathrm{~N}\right)$ Merck (98\%), Thiophene $\left(\mathrm{C}_{4} \mathrm{H}_{4} \mathrm{~S}\right)$ Merck (98\%), Imidazole $\left(\mathrm{C}_{3} \mathrm{~N}_{2} \mathrm{H}\right)($ 99\%), Acetonitrile $\left(\mathrm{C}_{2} \mathrm{H}_{3} \mathrm{~N}\right)$, Acetone $\left(\mathrm{C}_{3} \mathrm{H}_{6} \mathrm{O}\right)$, Methanol $\left(\mathrm{CH}_{3} \mathrm{OH}\right)$,THF (Tetrahydroforan), Ferric Chloride $\left(\mathrm{FeCl}_{3}\right)$, SDS $\mathrm{H}_{2} \mathrm{O}_{2}(35 \%)$, Cupric Bromide $\left(\mathrm{CuBr}_{2}\right)$, $\mathrm{Cud}_{2} .2 \mathrm{H}_{2} \mathrm{O}$, $\left(\mathrm{Cu}\left(\mathrm{NO}_{3}\right)_{2} .3 \mathrm{H} 2 \mathrm{O}\right), \mathrm{CuSO}_{4} .5 \mathrm{H}_{2} \mathrm{O}, \mathrm{DMS}, \mathrm{CuSO}_{4}, \mathrm{NiSO}_{4}, \mathrm{FeSO}_{4}$, $\mathrm{CoSO}_{4}$, Ammonium Peroxydisulphate, $\mathrm{HCl}(0.1 \mathrm{M})$, $\mathrm{NaOH}(0.1 \mathrm{M})$. Distilled water was used in the research work and all the solutions and dilutions were prepared from distilled water.

\subsection{Instrumentation}

Electrical grinder (ken wood), pH meter (HANN PH 211), Balance ER-120A (AND) and inductively coupled plasma (ICP-OES) Perkin Elmer optima 2100DV.SEM S-3400N (HITACHI)

\subsection{Synthesis of Polymers \\ 2.3.1 Synthesis of Polypyrrole}

For preparation of Polypyrrole, 3.35g of pyrrole (98\%) was weighed. 24.3g of $\mathrm{FeCl}_{3}$ was dissolved in $200 \mathrm{ml}$ of acetonitrile with good stirring. Then monomer was added slowly in 15 minutes. The precipitates were formed by keep stirring for one hour. Then solid was filtered and washed with methanol and acetonitrile and dried under vacuum. Then the product was extracted in soxhelet with THF, methanol and acetone until the extracted solvent was colorless. The polymer was washed with methanol and then with water. The polymer was dried under vacuum at $70^{\circ} \mathrm{C}$. After that the polymer was grinded. The particles size was examined by SEM analysis that was $279 \mathrm{~nm}$.Many other dopants i.e. $\mathrm{CuSO}_{4}, \mathrm{NiSO}_{4}, \mathrm{FeSO}_{4}, \mathrm{CoSO}_{4}, \mathrm{H}_{2} \mathrm{O}_{2}$ were used for polypyrrole but there was no significant results

\subsubsection{Synthesis of Polyaniline}

For preparation of Polyaniline, 2.59 of aniline (98\%) was taken and dissolved in $50 \mathrm{ml}$ distilled water. $0.02 \mathrm{~g}$ of ammonium peroxy dishulphate was also dissolved in $50 \mathrm{~mL}$ distilled water. Both solutions were kept for 1 hour. Then mixture was stirred for a day. The next day, the precipitates was collected on filter paper and $300 \mathrm{ml}$ of $0.2 \mathrm{M} \mathrm{HCl}$ was used to wash it and similarly procedure was done with acetone. Polyaniline powder was dried in air and then in vacuum at $60^{\circ} \mathrm{C}$ and the polymer was kept in a glass bottles .The particles size was measured as $410 \mathrm{~nm}$.

\subsubsection{Preparation of Polythiophene with $\mathrm{FeCl}_{3}$}

$3.35 \mathrm{~g}$ of thiophene monomer (98\%) was weighed $24.3 \mathrm{~g}$ of $\mathrm{FeCl}_{3}$ was dissolved in $200 \mathrm{ml}$ of acetonitrile with good stirring(Lim, Song et al. 2012). Then monomer was added slowly in 15 minutes, precipitates was formed but stirring was kept for one hour. Then precipitates was filtered and washed with methanol and acetonitrile. Then polymer was 
dried under vacuum. The product was extracted in soxhelet with THF, methanol, and acetone until the extracted solvent was colorless.The Polymer was washed with methanol and then with water, the polymer was dried under vacuum at $70{ }^{\circ} \mathrm{C}$ after that the polymer was grinded the particles size was 257 micro meter. The product was analyzed by SEM and FTIR technique and the product was used for the absorption of metal arsenic.

\subsubsection{Preparation of Polythiophene with $\mathrm{CuSO}_{4}$}

Polythiophene ware prepared with following method. The reaction was carried out $250 \mathrm{ml}$ flask with mechanical stirrer. Sodium dodecyde sulphates was weighed $0.1 \mathrm{~g}$ and $2 \mathrm{~g}$ of thiophene was added in $60 \mathrm{ml}$ deionized water and mixture was stirred at $300 \mathrm{rpm}$ for $20 \mathrm{~min}$. After that $9 \mathrm{~g}$ of $30 \% \mathrm{H} 2 \mathrm{O} 2$ solution was added $2 \times 10^{-4}$ moles of $\mathrm{CuSO} 4$ was added in $5 \mathrm{ml}$ water was added. The reaction was allowed to proceed for 7 hours. The polymer was precipitated by adding $\mathrm{HCl}$. Then by centrifugation we get polymer the ppts was washed may times with water the polymer was dried in vacuum at $0.50{ }^{\circ} \mathrm{C}$ for 48 hours. The particles size of polymer was about $200 \mu \mathrm{m}$.

\subsection{Batch experiments}

High purity chemicals and reagents, purchased from Sigma - Aldrich, Inc., were used during the experiment (1000 $\mathrm{mg} / \mathrm{L}$ ) stock solution of As (III) was prepared. Further dilutions were prepared daily as required. Different parameters i.e. adsorbent dose, contact time, $\mathrm{pH}$ and temperature were used for adsorption studies of arsenic from aqueous solution by using synthesized polymer as an adsorbent. Sample solution $(5 \mathrm{mg} / \mathrm{L}, 15 \mathrm{~mL})$ was taken in each flask. The amount of polymer was range from 0.02 $0.08 \mathrm{~g}$ was added. 4 measuring flasks $(100 \mathrm{ml})$ were dried in an oven at $105{ }^{\circ} \mathrm{C}$ for thirty minutes and labeled from 14.sample solution $(5 \mathrm{mg} / \mathrm{L}, 15 \mathrm{~mL})$ was taken in each flask . The $\mathrm{pH}$ of each sample was adjusted to $5-8$ by $0.1 \mathrm{M}$ HCL and $0.1 \mathrm{M} \mathrm{NaOH}$. The flasks were allowed to stay for 50 minutes. The temperature of each sample was adjusted as $55^{\circ} \mathrm{C}$. The solutions were filtered to remove the adsorbent and the emission for all filtrates was noted. The concentrations of the arsenic in water were determined with an inductively coupled plasma technique (Perkin-Elmer ICPOES Optima 2100) using standard working conditions. The percentage removal efficiency of adsorbent and adsorption capacity $\left(\mathrm{q}_{\mathrm{e}}\right)$ were calculated as follows,

$$
\begin{gathered}
\text { Percentage Removal (R \%) }=\frac{C_{0}-C_{e}}{C_{0}} \times 100 \\
q_{e}=\left(C_{0}-C_{e}\right) \times \frac{V}{m}
\end{gathered}
$$

where $C_{0}(\mathrm{mg} / \mathrm{L})$ and $C e(\mathrm{mg} / \mathrm{L})$ are the initial and equilibrium concentration of metal ions in solution respectively. $\mathrm{V}(\mathrm{L})$ is the volume of the solution and $\mathrm{m}(\mathrm{g})$ is the dry mass of the adsorbent.

\section{Results and discussion \\ 3.1 FT-IR analysis}

Fourier transform infrared spectroscopy (FTIR) was used to analyze the structure of the polypyrrole. The spectra were obtained at I.R. prestige-21. Resolution $4 / \mathrm{cm}$. wavenumber: $4000-8000 \mathrm{~cm}^{-1}, 70$ scans. The Fig $1 \mathrm{a}$ shows the FTIR spectrum. A broad peak shows at $3448 \mathrm{~cm}^{-1}$ is the characteristic peak of $\mathrm{N}-\mathrm{H}$ stretching mode. The peak at $1631 \mathrm{~cm}^{-1}$, is $\mathrm{C}=\mathrm{C}$ stretching of pyrrole ring. The peak at $1174 \mathrm{~cm}^{-1}$, is the $\mathrm{C}-\mathrm{C}$ stretching of pyrrole. The spectra after adsorption in Fig.1b shows the same peaks with lot of other small peaks, that is because of metal ions attachment. The small peaks in IR spectra show the adsorption of metal ions on polymer.

Polyaniline has the prominent peak in Fig at $3417 \mathrm{~cm}^{-1}$ that represents the presence of N-H bond, $1566 \mathrm{~cm}^{-1}$ and $1477 \mathrm{~cm}^{-1}$ peak are attributed to Quinone and benzene rings changes, during the polymerization process (Palaniappan 2001). The IR spectra after adsorption in Fig $1 \mathrm{~b} 1$ depict small peaks that indicates the presence of metal ion attachment on polymer back bone.

Considering IR spectra's of polythiophene ,the band at 783 $\mathrm{cm}^{-1}$ can be assigned to $\mathrm{C}-\mathrm{S}-\mathrm{C}$ bonding and the characteristic peak is $1026 \mathrm{~cm}^{-1}$ that is of $=\mathrm{C}-\mathrm{S}$. The $\mathrm{C}=\mathrm{C}$ frequency occurs at $1443-1523 \mathrm{~cm}^{-1}$. The band at $1377 \mathrm{~cm}^{-1}$ probably due to C-C bonds. The IR spectra's of polythiophene after adsorption also shows similar peaks. There are many small additional peaks that are due to metal ions interference with polymer.

\subsection{SEM analysis}

SEM analysis revealed that polyaniline has sponge structure and particle size ranges in $\mathrm{nm}$ in Fig 2a. Polypyrrole has cloudy structure and particle size ranges in $\mathrm{nm}$ (Fig 2b). Polythiophene has defused structure and polythiophene 2 has granular structure with particle size ranges in $\mu \mathrm{m}$ (Fig 2c).

\subsection{Adsorption parameters \\ 3.3.1 Effect of Polymers dose}

It was observed that adsorption yield increase at high adsorbent dose for polypyrol, polyanaline, polythiophene and polythiophine 2 . It is clear from figure $3 a$ that the minimum adsorption of As (III) ions was $69 \%, 26 \%, 56 \%$ and $57 \%$ for dose of $0.02 \mathrm{~g} / \mathrm{L}, 0.02 \mathrm{~g} / \mathrm{L}, 0.04 \mathrm{~g} / \mathrm{L}$ and $0.02 \mathrm{~g} / \mathrm{L}$

(1) of polypyrol, polyanaline, polythiophene and polythiophine 2 , respectively and maximum adsorption value was $97 \%$, $92 \%, 86 \%$ and $83 \%$ respectively for the dose $0.08 \mathrm{~g} / \mathrm{L}$ for $5 \mathrm{ppm}$ initial concentration of arsenic solution (Fig 3a) for prepared polymers. This increase in adsorption with 
Internat. J. Sci. Eng. Vol. 6(2)2014:154-162, April 2014, Muhammad Imran Din et al.

increase in adsorbent dose is due to the availability of more sites also increases so there is a gradual increase in the adsorption sites. As the dose increases the number of active adsorption with the increase of dose.

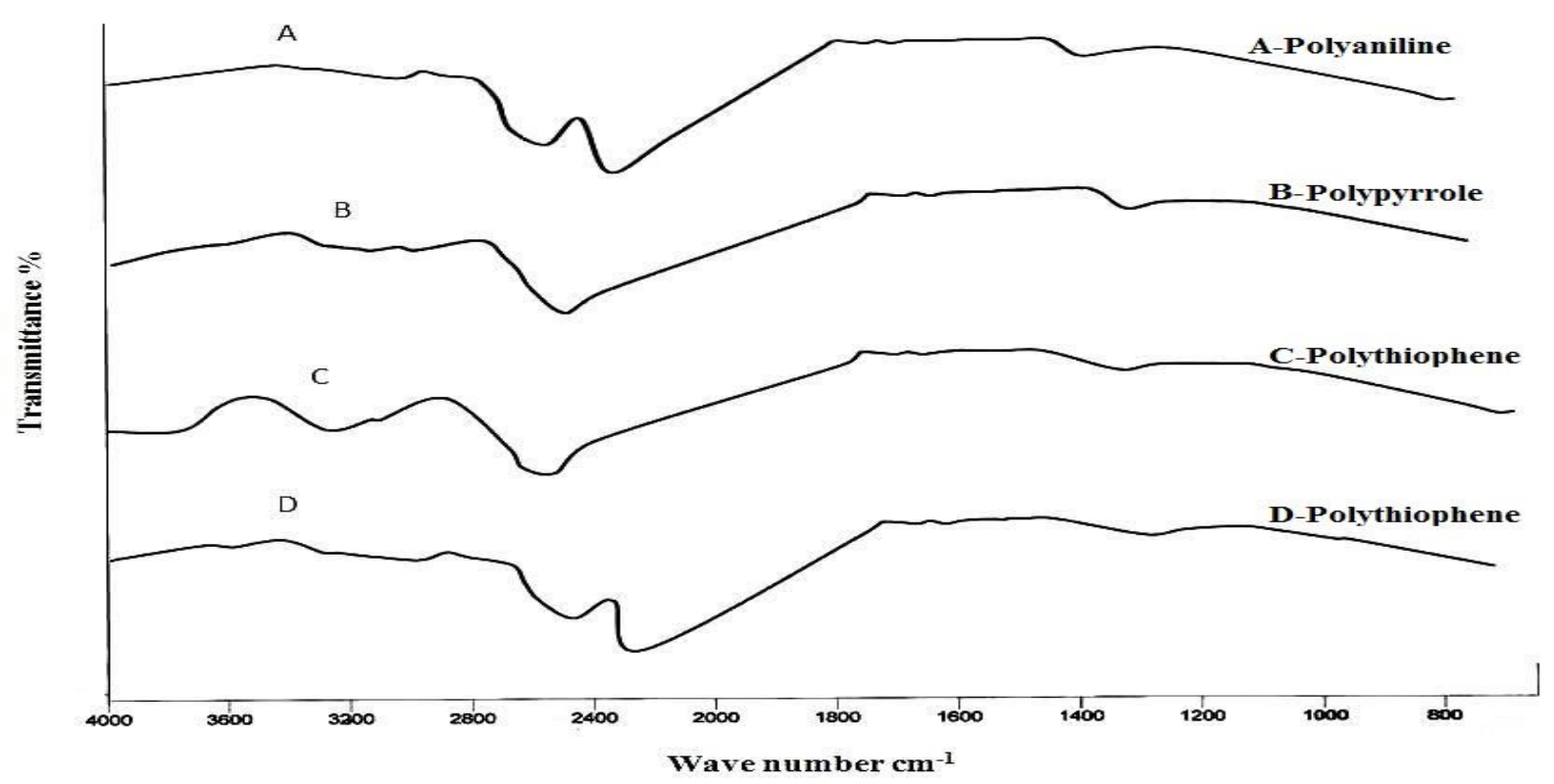

Fig 1a: FT-IR of Polyaniline, Polypyrrole and Polythiophene

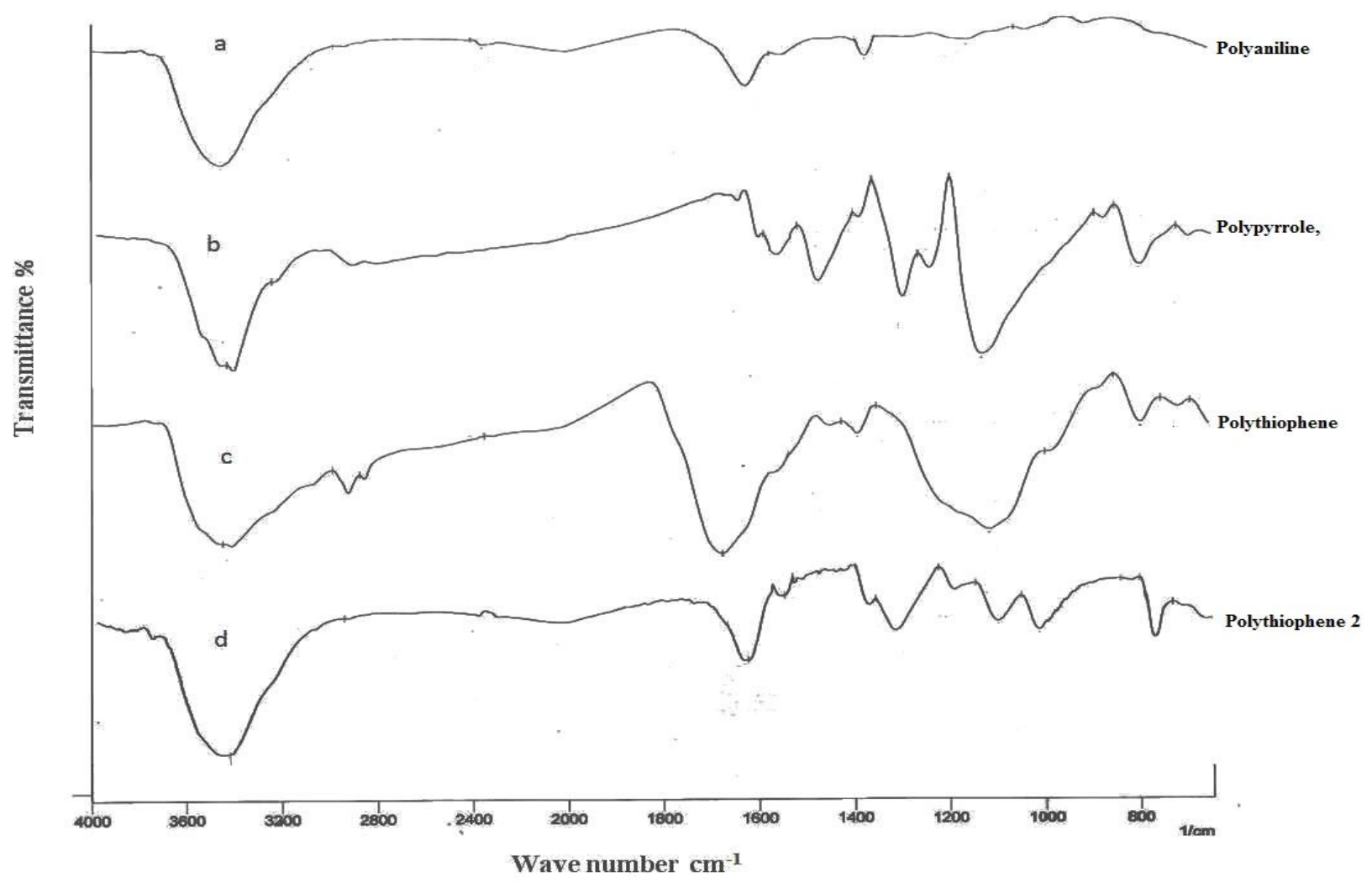

Fig 1b: FT-IR of As (III)-Polyaniline, As (III)-Polypyrrole and As (III)-Polythiophene 


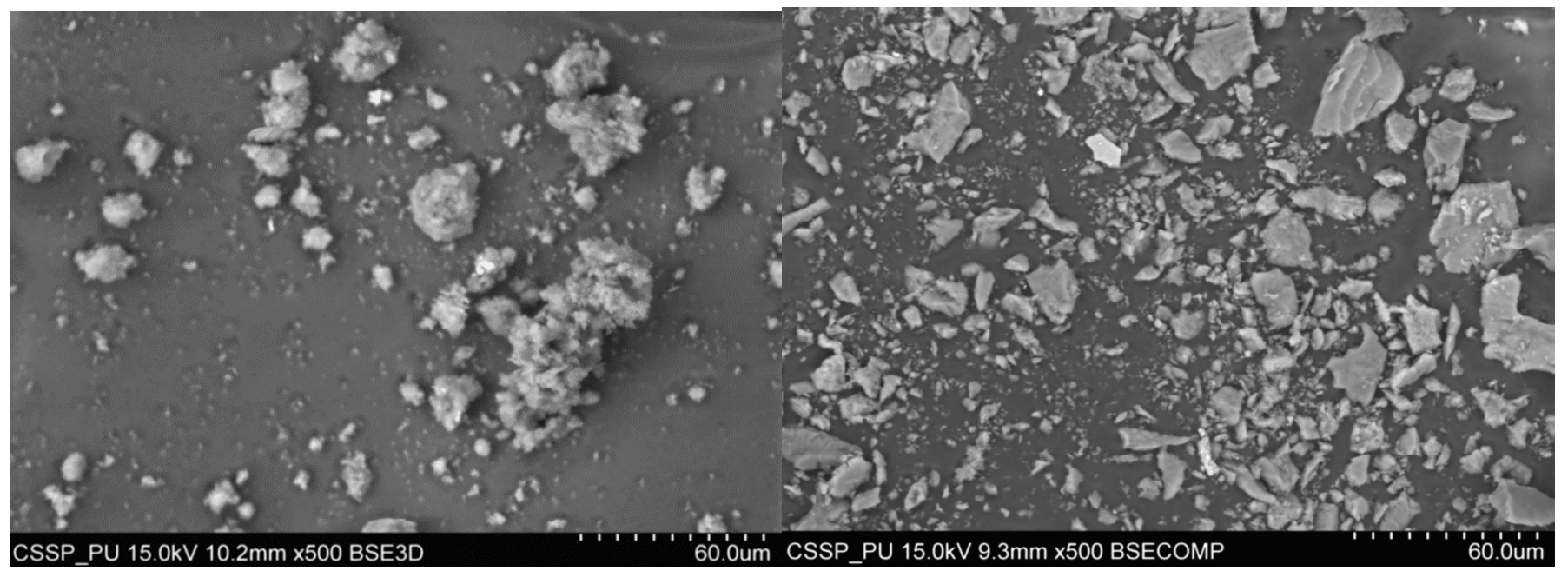

(a) (b)

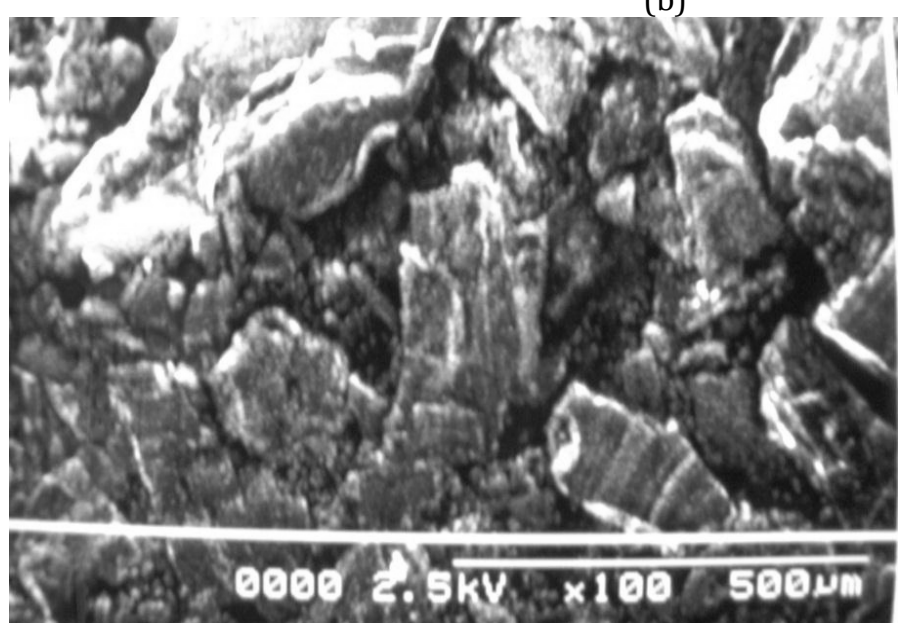

(c)

Figure 2. (a) SEM image of Polyaniline; (b) SEM image of Polypyrrole; (c) SEM image of Polythiophene

\subsubsection{Time of contact}

Contact time studies are very important as it reveal the minimum time for maximum removal. The effect of various contact time on adsorption was studied. The result is shown in Fig 3b maximum adsorption value for polypyrrole, polyaniline, polythiophene and polythiophine- 2 was $75 \%$, $83 \%, 88 \%$ and $86 \%$ for the time $20,10,10$ and 40 minutes respectively.The higher adsorption rates of metal ions are due to vacant sites available at initial stages .This is because of strong attractive forces between metal ions and adsorbents. As the time preceded the adsorption decreases as the equilibrium has been established. Further increase in contact time has no remarkable effect on removal efficiency.

\subsubsection{Effect of $\mathrm{pH}$}

The $\%$ age of adsorption was studied as a function of $\mathrm{pH}$ in the range of 5-6. The result is shown in Fig 3c.The maximum adsorption for Polypyrrole, Polyaniline, polythiophene, and polythiophene-2 was $92 \%, 81 \%, 81 \%$ and $88 \%$ at $\mathrm{pH} 7,5,5$ and 7 respectively for $5 \mathrm{ppm}$ initial concentration of arsenic solution and again starts decreasing at PH 8. This could be due to the weakening of electrostatic force of attraction between the oppositely charged adsorbate and adsorbent that ultimately lead to the reduction in \% age adsorption .Negatives charges are necessary for the adsorption of metal ions. $\mathrm{H}^{+}$ions competes with metal ions at low $\mathrm{pH}$. Adsorbent surface was become positively charged and the attraction was reduced between adsorbent and metal ions .At high $\mathrm{pH}$, the surface become negatively charged and the metal uptake increases. At higher $\mathrm{pH}$ solubility of metal decreases that result in precipitation as hydroxide.

\subsubsection{Effect of temperature}

It was observed that adsorption yield decrease with increase in temperature. The maximum adsorption for Polypyrrole, Polyaniline, polythiophene, and polythiophene- 2 was $70 \%, 83 \%, 76 \%$ and $92 \%$ at $45^{\circ} \mathrm{C}$, 
Internat. J. Sci. Eng. Vol. 6(2)2014:154-162, April 2014, Muhammad Imran Din et al.

$25^{\circ} \mathrm{C}, 25^{\circ} \mathrm{C}$ and $45^{\circ} \mathrm{C}$ for $5 \mathrm{ppm}$ initial concentration of arsenic solution (Fig $3 \mathrm{~d}$ ). Increase in the adsorption with increase of temperature because energy is required for binding of metal ions. The \%age removal decreases at high temperature because molecules move with great velocity and less time of interaction. The adsorbent can also be denatured and the bond between metal ions and adsorbent weekend.

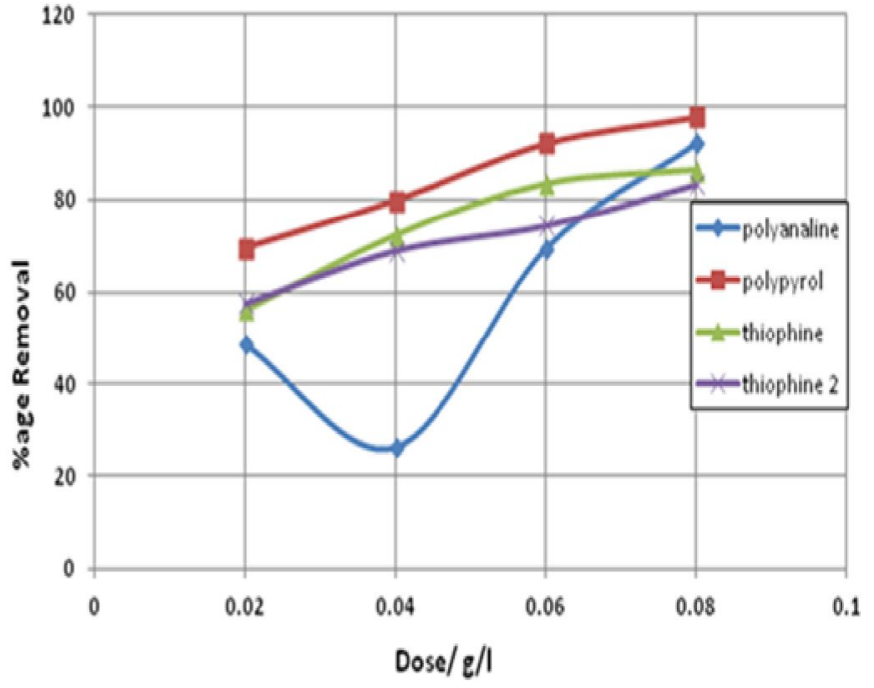

(a)

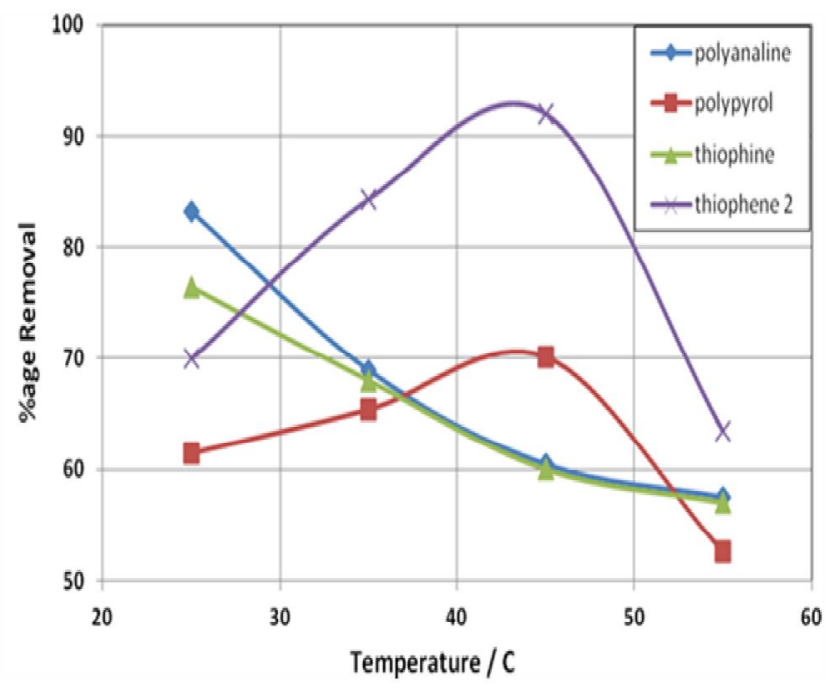

(c)

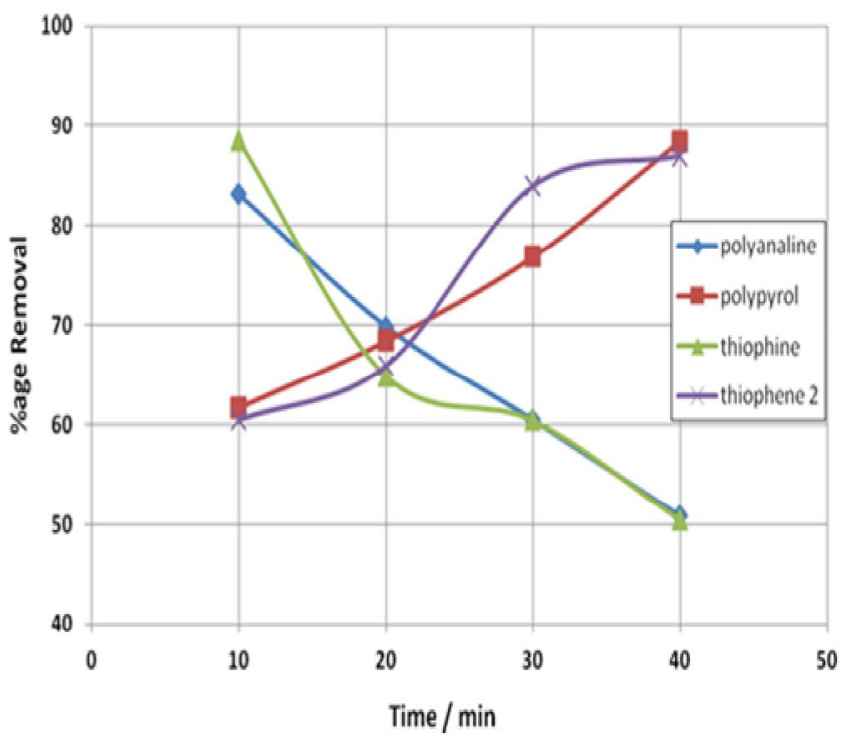

(b)

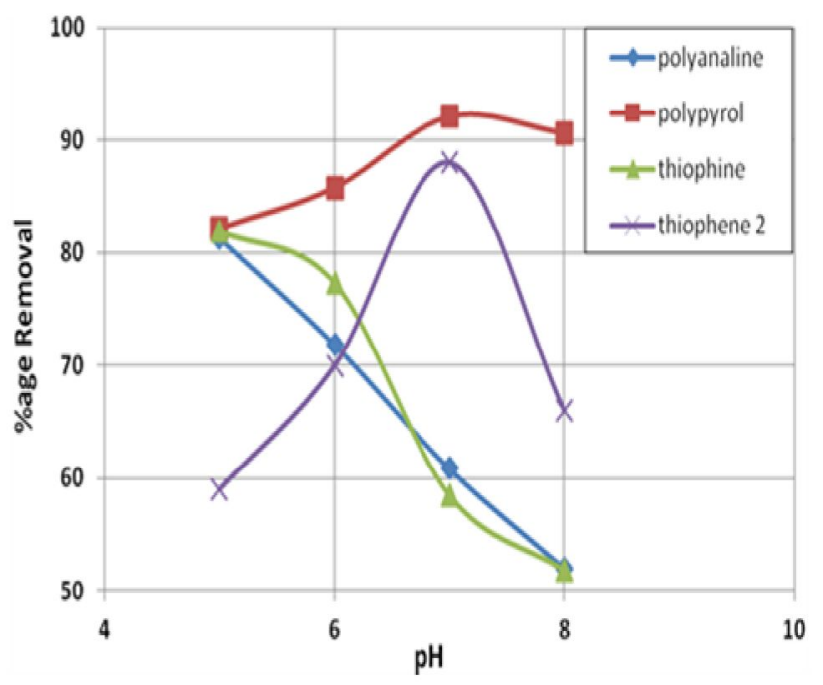

(d)

Figure 3. (a) Effect of amount of Polyaniline, Polypyrrole and Polythiophene on adsorption of Arsenic; (b). Effect of contact time for adsorption of As (III) on Polyaniline, Polypyrrole and Polythiophene; (c). Effect of pH for adsorption of As (III) on Polyaniline, Polypyrrole and Polythiophene; (d). Effect of temperature for adsorption of As (III) on Polyaniline, Polypyrrole and Polythiophene

\subsection{Adsorption Isotherms}

The experimental data was evaluated using different isotherm models: Langmuir (Eq.3) Freundlich (Eq. 4), Dubinin-Radushkevich (Eq.5), Redlich-Peterson (Eq.6) and Toth (Eq.7) (Sağ, Akçael et al. 2001; Ncibi 2008; Foo and Hameed 2010; Zakhama, Dhaouadi et al. 2011). To find the best fit isotherm model, correlation coefficients $\left(\mathrm{R}^{2}\right)$ and chi square test $\left(\chi^{2}\right)$ were carried out for linear and non-linear methods(Foo and Hameed 2010; Din and Mirza 2013; Imran Din, Mirza et al. 2013). 


$$
\begin{gathered}
q_{e}=\frac{K_{L} \cdot q_{m} \cdot C_{e}}{1+K_{L} \cdot C_{e}} \\
q_{e}=K_{f} C_{e}^{1 / n} \\
q_{e}=q_{D R} e^{-\beta \varepsilon^{2}} \\
q_{e}=\frac{K_{R P} C_{e}}{1+a_{R P} C_{e}^{\beta}} \\
q_{e}=\frac{K_{T} C_{e}}{\left(a_{T}+C_{e}\right)^{1 / t}}
\end{gathered}
$$

Where $\mathrm{q}_{\mathrm{e}}\left(\mathrm{mg}^{\mathrm{g}} \mathrm{g}^{-1}\right)$ is equilibrium uptake corresponding to $\mathrm{C}_{\mathrm{e}}\left(\mathrm{mg} \cdot \mathrm{L}^{-1}\right)$ the equilibrium concentration of $\mathrm{As}^{+3} \cdot \mathrm{K}_{\mathrm{L}}\left(\mathrm{L} \cdot \mathrm{mg}^{-1}\right)$ and $\mathrm{q}_{\mathrm{m}}\left(\mathrm{mgg}^{-1}\right)$ are the Langmuir constants.

$\mathrm{K}_{\mathrm{f}}\left(\mathrm{mg} \cdot \mathrm{g}^{-1}\right)$ and $\mathrm{n}$ are Freundlich constants. $\mathrm{K}_{\mathrm{f}}$ represents the relative adsorption capacity of the biosorbent. Value of $n$ signifies the strength of biosorption.

$\mathrm{q}_{\mathrm{e}}(\mathrm{mg} / \mathrm{g})=$ adsorption capacity at equilibrium; $\beta$ is the constant connected with the mean free energy of adsorption per mole of the adsorbate $\left(\mathrm{mol}^{2} \cdot \mathrm{kJ}^{-2}\right) ; \mathrm{q}_{\mathrm{DR}}$ is the theoretical saturation capacity $(\mathrm{mg} / \mathrm{g}) ; \mathrm{K}_{\mathrm{RP}}\left(\mathrm{L} \cdot \mathrm{g}^{-1}\right)$ and $\mathrm{a}_{\mathrm{RP}}\left({\mathrm{L} . m g^{-1}}^{\beta}{ }^{\beta}\right.$ and $\beta$ are Redlich-Peterson constants. $\mathrm{K}_{\mathrm{T}}\left({\mathrm{L} . \mathrm{g}^{-1}}^{-1}\right.$, $\mathrm{a}_{\mathrm{T}}\left(\mathrm{L}^{\mathrm{mg}} \mathrm{g}^{-1}\right)$ and $\mathrm{t}$ which are Toth's constants

\section{Non-linear method}

A trial and error procedure was developed to determine the isotherm parameters by maximizing the correlation coefficient between the experimental data points and theoretical model predictions using the solver add-in function of the Microsoft excel 2007 software (Microsoft, USA) (Din and Mirza 2013).

\section{Nonlinear chi-square test $(\chi 2)$}

The nonlinear chi-square test $\left(\chi^{2}\right)$ is a statistical tool required for the best fit of an adsorption system, it is represented as

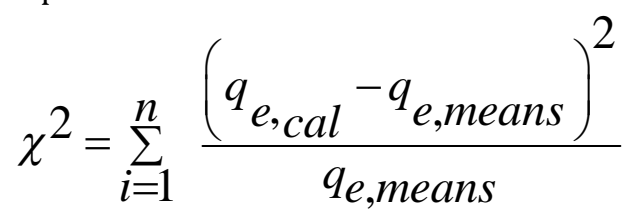

(8)

Large value of $\left(\chi^{2}\right)$ indicates variation while its small value shows similarities of the experimental data(Ncibi 2008).

Table 1 and Figure 4(a-c) shows the experimental data and the predicted values by non-linear method. The Langmuir and Dubinin-Radushkevich isotherm have almost the same and low chi-square test $(\chi 2)$ values. It can be observed that among two parameters isotherms the adsorption of As (III) on polypyrrole, polyaniline and polythiophene follow Freundlich isotherm, which indicates that the uptake occurs on a heterogeneous surface by multilayer adsorption.

The Toth model correctly pretends the adsorption

\begin{tabular}{|c|c|c|c|c|c|c|c|c|c|c|c|c|}
\hline Isotherm & \multicolumn{4}{|c|}{$\frac{\text { Polyaniline }}{ \pm \text { SD } \chi 2}$} & \multicolumn{4}{|c|}{ Polypyrrole } & \multicolumn{4}{|c|}{$\frac{\text { Polythiophene }}{ \pm S D \chi^{2}}$} \\
\hline Langmuir & $\begin{array}{l}\mathrm{q}_{\mathrm{m}} \\
\mathrm{K}_{\mathrm{L}}\end{array}$ & $\begin{array}{c}4.2 \\
99.4\end{array}$ & $\begin{array}{l}0.22 \\
11.5\end{array}$ & 0.022 & $\begin{array}{l}\mathrm{q}_{\mathrm{m}} \\
\mathrm{K}_{\mathrm{L}}\end{array}$ & $\begin{array}{l}23 \\
0.9\end{array}$ & $\begin{array}{l}7.66 \\
0.43\end{array}$ & 0.712 & $\begin{array}{l}\mathrm{q}_{\mathrm{m}} \\
\mathrm{K}_{\mathrm{L}}\end{array}$ & $\begin{array}{l}2.61 \\
37.8\end{array}$ & $\begin{array}{l}0.24 \\
0.01\end{array}$ & 0.084 \\
\hline Freundlich & $\begin{array}{c}\mathrm{K}_{\mathrm{F}} \\
\mathrm{n}\end{array}$ & $\begin{array}{l}5.68 \\
1.41 \\
\end{array}$ & $\begin{array}{l}0.61 \\
1.41 \\
\end{array}$ & 0.02 & $\begin{array}{c}\mathrm{K}_{\mathrm{F}} \\
\mathrm{n}\end{array}$ & $\begin{array}{l}12.1 \\
1.41 \\
\end{array}$ & $\begin{array}{l}0.79 \\
0.18\end{array}$ & 0.635 & $\begin{array}{c}\mathrm{K}_{\mathrm{F}} \\
\mathrm{n}\end{array}$ & $\begin{array}{l}5.48 \\
2.53 \\
\end{array}$ & $\begin{array}{l}1.75 \\
0.71 \\
\end{array}$ & 0.059 \\
\hline D-R & $\begin{array}{l}\mathrm{q}_{\mathrm{s}} \\
\beta\end{array}$ & $\begin{array}{c}4.5 \\
2 \mathrm{E}^{-008}\end{array}$ & $\begin{array}{c}0.2 \\
1 \mathrm{E}^{-009}\end{array}$ & 0.017 & $\begin{array}{l}\mathrm{q}_{\mathrm{s}} \\
\beta\end{array}$ & $\begin{array}{c}12 \\
2 \mathrm{E}^{-008}\end{array}$ & $\begin{array}{c}1.09 \\
5 E^{-008}\end{array}$ & 0.992 & $\begin{array}{l}\mathrm{q}_{\mathrm{s}} \\
\beta\end{array}$ & $\begin{array}{c}3.02 \\
4 \mathrm{E}^{-008}\end{array}$ & $\begin{array}{c}0.54 \\
1 E^{-008}\end{array}$ & 0.069 \\
\hline R-P & $\begin{array}{c}\mathrm{K}_{\mathrm{R}} \\
\mathrm{a}_{\mathrm{R}} \\
\mathrm{g}\end{array}$ & $\begin{array}{c}193 \\
84 \\
1.2\end{array}$ & $\begin{array}{c}0.002 \\
0.003 \\
0.7\end{array}$ & 0.004 & $\begin{array}{c}\mathrm{K}_{\mathrm{R}} \\
\mathrm{a}_{\mathrm{R}} \\
\mathrm{g}\end{array}$ & $\begin{array}{c}20.1 \\
0.83 \\
1\end{array}$ & $\begin{array}{l}0.43 \\
0.38 \\
0.18\end{array}$ & 0.761 & $\begin{array}{c}\mathrm{K}_{\mathrm{R}} \\
\mathrm{a}_{\mathrm{R}} \\
\mathrm{g}\end{array}$ & $\begin{array}{c}176 \\
40 \\
0.75\end{array}$ & $\begin{array}{c}0.004 \\
0.014 \\
0.68\end{array}$ & 0.068 \\
\hline Toth & $\begin{array}{c}\mathrm{K}_{\mathrm{T}} \\
\mathrm{a}_{\mathrm{T}} \\
\mathrm{t}\end{array}$ & $\begin{array}{l}1.11 \\
0.07 \\
0.51\end{array}$ & $\begin{array}{c}1 \\
0.05 \\
0.2\end{array}$ & 0.003 & $\begin{array}{c}\mathrm{K}_{\mathrm{T}} \\
\mathrm{a}_{\mathrm{T}} \\
\mathrm{t}\end{array}$ & $\begin{array}{c}12.5 \\
0.18 \\
6.5\end{array}$ & $\begin{array}{l}1.51 \\
0.13 \\
0.52\end{array}$ & 0.83 & $\begin{array}{c}\mathrm{K}_{\mathrm{T}} \\
\mathrm{a}_{\mathrm{T}} \\
\mathrm{t}\end{array}$ & $\begin{array}{l}1.37 \\
0.06 \\
0.71\end{array}$ & $\begin{array}{c}0.43 \\
.031 \\
0.5\end{array}$ & 0.105 \\
\hline
\end{tabular}
isotherms of As (III) on polypyrrole, polyaniline and polythiophene. The chi-square $(\chi 2)$ value was much low indicated in Table 1.

Table1: Non-Linear adsorption isotherms parameters for adsorption of As (III) on Polyaniline, Polypyrrole and Polythiophene 


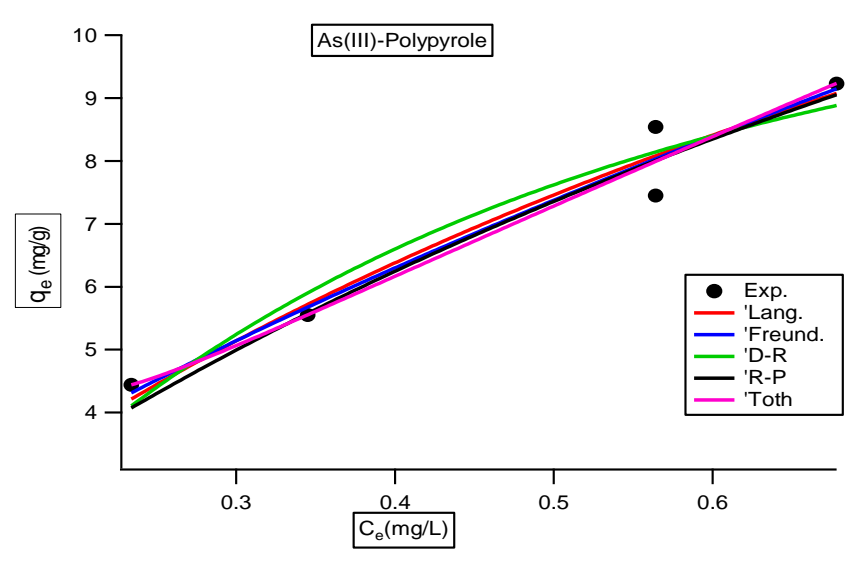

(a)

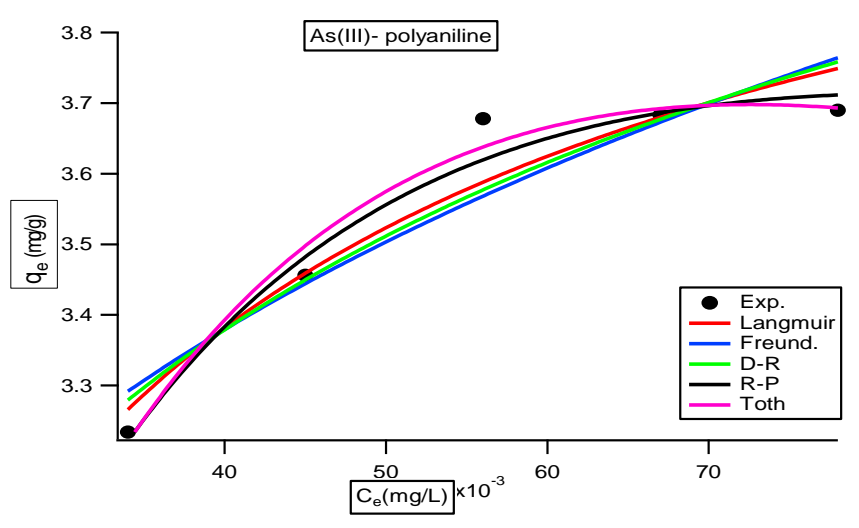

(b)

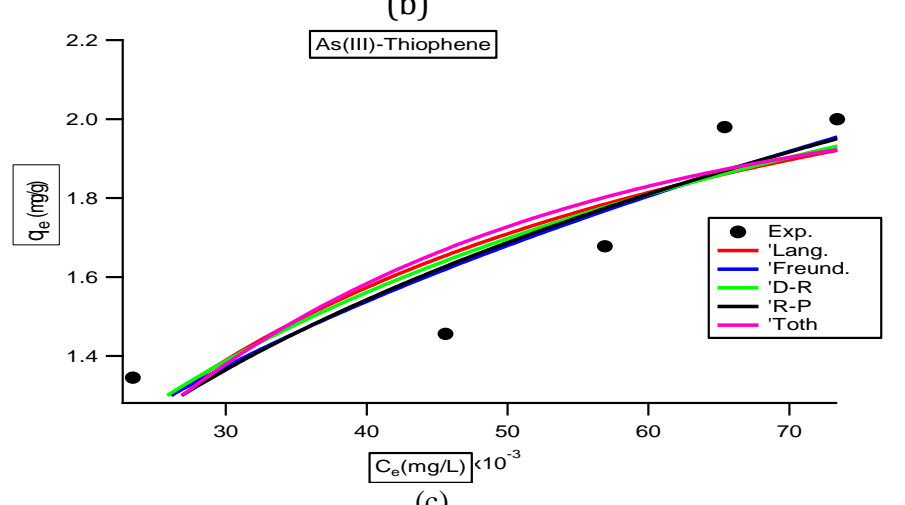

(c)

Figutre 4. (a) Non-Linear Langmuir, Freundlich, D-R, R-P and Toth Isotherms for adsorption of As (III) ions on Polyaniline; (b) NonLinear Langmuir, Freundlich, D-R, R-P and Toth Isotherms for adsorption of As (III) ions on Polypyrole ; (c) Non-Linear Langmuir, Freundlich, D-R, R-P and Toth Isotherms for adsorption of As (III) ions on Polythiophene

\section{Conclusion}

Polypyrrole, polyaniline and polythiophene are important conductive polymers. These can easily be synthesized through chemical polymerization .These polymers were characterized by FTIR and SEM analysis. The micrographs showed that the particle size was ranged in nanometer. Polypyrrole and polyaniline are cheap and environment friendly. But polythiophene is expensive and it should be prepared in the non-aqueous media because of insolubility in water. Among these polymers, polythiophene proved be a better adsorbent for Arsenic removal from aqueous solution. The optimum conditions for its removal were dose 0.08 , temperature $25^{\circ} \mathrm{C}, \mathrm{pH} 7$ and contact time 20 minutes. Arsenic removal was largely depends on $\mathrm{pH}$. Based on standard deviation (SD) and Chi square test $\left(\chi^{2}\right)$, the experimental data was best explained by Freundlich and Toth isotherm.

\section{REFERENCES}

Ansari, R. , Fahim, N. K. (2007). "Application of polypyrrole coated on wood sawdust for removal of $\mathrm{Cr}(\mathrm{VI})$ ion from aqueous solutions." REACTIVE AND $\begin{array}{llll}\text { FUNCTIONAL } & \text { POLYMERS } & \text { 67(4): } & \text { 367-374; }\end{array}$ http://www.trisanita.org/jases/asespaper2010/ases24v5n3y2010.pdf

Carvalho, W. A., Vignado, C. et al. (2008). "Ni(II) removal from aqueous effluents by silylated clays." JOURNAL OF HAZARDOUS MATERIALS 153(3): $1240-1247$

http://www.sciencedirect.com/science/article/pii/S0304389407013763 Din, M. I. , Mirza, M. L. (2013). "Biosorption potentials of a novel green biosorbent Saccharum bengalense containing cellulose as carbohydrate polymer for removal of $\mathrm{Ni}$ (II) ions from aqueous solutions." INTERNATIONAL JOURNAL OF BIOLOGICAL MACROMOLECULES 54(0): 99-

108

http://www.sciencedirect.com/science/article/pii/S0141813012004400

Foo, K. Y.,Hameed, B. H (2010). "Insights into the modeling of adsorption isotherm systems." CHEMICAL ENGINEERING JOURNAL 156(1): 2-10;

http://www.sciencedirect.com/science/article/pii/S1385894709006147 Imran Din, M., Mirza, M. L.,et al. (2013). "Thermodynamics of Biosorption for Removal of Co(II) Ions by an Efficient and Ecofriendly Biosorbent (Saccharum bengalense): Kinetics and Isotherm Modeling." E-JOURNAL OF CHEMISTRY 2013: 11; http://www.hindawi.com/journals/chem/2013/528542/

Katsoyiannis, I. A. ,. Zouboulis ,A. I. (2002). "Removal of arsenic from contaminated water sources by sorption onto iron-oxide-coated polymeric materials." WATER RESEARCH 36(20): 5141-5155; http://www.sciencedirect.com/science/article/pii/S0043135402 002361

Kumaresan, M. , Riyazuddin, P. (2001). "Overview of speciation chemistry of arsenic." CURRENT SCIENCE 80(7): 837-846; http://www.currentscience.ac.in/Downloads/article_id_080_07_0 837_0846_0.pdf

Lashkenari, M. S., Davodi . B. et al. (2011). "Removal of arsenic from aqueous solution using polyaniline/rice husk nanocomposite." KOREAN JOURNAL OF CHEMICAL ENGINEERING 28(7): 1532-1538; http://www.cheric.org/research/tech/periodicals/view.php?seq= 890400

Lim, C. W.,. Song, K. et al. (2012). "Synthesis of PPy/silica nanocomposites with cratered surfaces and their application in heavy metal extraction." JOURNAL OF INDUSTRIAL AND ENGINEERING CHEMISTRY 18(1): 24-28; http://infosys.korea.ac.kr/research/tech/periodicals/view.php?se $\mathrm{q}=912901$ 
Internat. J. Sci. Eng. Vol. 6(2)2014:154-162, April 2014, Muhammad Imran Din et al.

Lo, S.-L... Jeng, H.-T., et al. (1997). "Characteristics and adsorption properties of iron-coated sand." WATER SCIENCE AND TECHNOLOGY 35(7): 63-70 http://www.sciencedirect.com/science/article/pii/S0273122397 001157

Ncibi, M. C. (2008). "Applicability of some statistical tools to predict optimum adsorption isotherm after linear and non-linear regression analysis." JOURNAL OF HAZARDOUS MATERIALS 153(12): 207-212; http://www.sciencedirect.com/science/article/pii/S0304389407 012150

Palaniappan, S. (2001). "Chemical and electrochemical polymerization of aniline using tartaric acid." EUROPEAN POLYMER JOURNAL 37(5): 975-981;

http://www.sciencedirect.com/science/article/pii/S0014305700 00207

Sağ, Y., Akçael, B., et al. (2001). "Evaluation, interpretation, and representation of three-metal biosorption equilibria using a fungal biosorbent." PROCESS BIOCHEMISTRY 37(1): 35-50;
http://www.sciencedirect.com/science/article/pii/S0032959201 001716

Vidal, J. C. ,García, E. et al. (1999). "In situ preparation of a cholesterol biosensor: entrapment of cholesterol oxidase in an overoxidized polypyrrole film electrodeposited in a flow system: Determination of total cholesterol in serum." ANALYTICA CHIMICA ACTA 385(13):

213-222;

http://www.sciencedirect.com/science/article/pii/S0003267098 008381

Zakhama, S., Dhaouadi, H.,et al. (2011). "Nonlinear modelisation of heavy metal removal from aqueous solution using Ulva lactuca algae." BIORESOURCE TECHNOLOGY 102(2): 786-796; http://www.sciencedirect.com/science/article/pii/S0960852410 014926

Zhao, X., Lv, L.,et al. (2011). "Polymer-supported nanocomposites for environmental application: A review." CHEMICAL ENGINEERING JOURNAL 170(2): 381-394; http://www.sciencedirect.com/science/article/pii/S1385894711 002804 